\title{
弾性状態にある砂の構成式 \\ CONSTITUTIVE EQUATION OF COHESIONLESS \\ SAND IN ELASTIC STATE
}

\author{
村山 朔 郎* \\ By Sakuro MURAYAMA
}

\section{1. 緒言}

\section{(1) 土の構成式}

材料の構成式 (constitutive equation)は, 材料に与え られた外部からの作用とその応答との関係を示寸条件式 であって，材料を形成する物質の物性と構成から定まる 材料の外作用に対する特異性をあらわしているものとい えよう。材料を仮りに電気機器にたとえれば, 機器の構 成部品とそれらを結ぶ配線によって決定される入出力特 性に似ている。通常土に与えられる外作用は種々の温度 のもとで与えられる応力や変形またはその時間的変量で あるから,土の構成式は stress-strain-time-temperature 関係として示されることが多い。

従来土質力学の分野では地盤の安定問題が主に扱わ れ，そのため塑性時における力のつり合いを論じたもの が多く、変形や時間を扱った理論には圧密理論くらいし かみられなかった。しかし土質力学の問題は安定問題だ けではない。土の各種の力学的問題を解明するには変 形・時間の要素が必要であり, 土質力学を完全な体系の 材料力学に仕上げるには土の普遍的な構成式の確立から 出発せねばならない。

もし土の構成式が明らかになれば，これを土の mass である地盤に適用して地盤内の応力・ひずみの解析, 破 壊の予知, 動的特性などを解析することができよう。土の 構成式の地盤への適用法には種々あるが 1960 年 Clough が開発した有限要素法 (finite element method) は最 近のコンピューターの進歩にともない非常に有力なもの の一つであろう。その際土の構成式はコンピューターの in put となるものであるから, 地盤の応力, ひずみ分 布などの out put の正確を期するためには, 正しくか つ普遍性のある土の構成式の解明が望まれる。

* 正会員 工博 京都大学教授 防災研究所
土質力学では従来から土の stress-strain 関倸は種々 実験され，またこれより応力・ひずみの実験式を求めた ものもあるが, とかく特定条件下の関係であって普遍性 は必ずしも十分とはいえない。一方構成式を種々の立場 から理論的に解明しようとする試みが最近みられるよう になってきつつあるがまだ土の構成特性を stress-strain の広い範囲にわたって示すほどにはなっていないようで ある。

土の構成式を理論的に求めるには，おおむね次のよう な方法がある。第 1 の方法は, 土の内部構成にはあまり 立入らず，巨視的な土の特性について普遍的な関係を求 めようとするいわば現象論的な立場からの方法である。 第 2 の方法は, 土の微視的な内部構成を考慮して, それ に基づいた微視的な局所特性を求め, その累積として土 の巨視的な構成関倸を誘導しようとする物性論的な方法 である。第 1 の方法には弾性理論や塑性理論などの体系 化された既成理論を導入する余地が多く，この手法に属 する研究はすでにいくらか報告されている。第 2 の方法 では, 従来土のような材料を扱った材料力学がほとんど なかったので, 土質力学のためにはそれに適合した新た な手法を案出していか祇ばならない困難があるが，それ だけ土の内部構成の本質に近づくことができる可能性が 多い。本文は, 第 2 の方法の立場をとり, その解明のた めには統計力学的な手法を導入したものである。

\section{（2）砂の力学特性に関する従来の理論的研究}

砂の力学特性を理論的に研究しょうとする試みは, せ 儿断時の強度特性を解明することに主眼をおいた研究に 多くみられるが，せん断時の応力・ひずみ特性までも研 究したものはきわめて少ない。

そのため筆者は, 1964 年に砂の粒子構成における不 規則性を考慮して, せん断時の粒子状態を統計力学的に 解明し, 弾性状態にある砂の構成式の誘導を試み, つい で 1969 年にはこれを抁張して塑性状態および破壊状態 
にある砂の構成関係を報告しだ”。

その頃の前後に発表された砂の力学的特性に関する理 論的な研究では, それらの内容ははじめにのべたようで あるが，それらの考察の方法は，せん断時の巨視的特性 に対する現象論的な考察によるものが多く, 砂内部の微 視的粒子構成に立脚した物性論的な考察によるものはき わめて少ない。ここでは, それらの研究のらち, 粒子レ ベルの微視的考察に立脚しているものを紹介寸る。

P.L. Newland and B.H. Allely (1957) ${ }^{2)}$ は, 砂中 の各粒子注，せん断時には粒子ぞうしの接触面をいわゆ る摩擦斜面として滑動するとして, 砂のせん断強度と残 留強度のちがいを, 粒子接点の移動時に㧍ける摩擦斜面 の傾斜角の差異から説明しようとした。さらに砂のダイ ラタンシー特性と摩擦斜面の傾斜角とを関係づけ, 砂の 主応力比とダイラタンシーの関係を考察した。

P.W. Rowe $(1962)^{3)}$ は, 等大径の丸俸または等大径 の球が規則配列をしている集合体を想定し，その主応力 比・ダイラタンシー関係を求めるために, 摩擦斜面の要 素である粒子間摩擦や粒子どうしの接触面の傾斜角のほ かに, 粒子の幾何学的配列を示寸倸数を加えて, 粒子間 の力のつり合いからこの集合体のせん断強度・ダイラタ ンシー特性を求めた。さらに不規則な粒子配列の場合に 対しては，粒子間のすべりによって生ずる内部仕事量が 最小になるように粒子どうしの接触面が再配列されると して, 規則配列に対して求めた関係を拡張した。

最上 $(1965 ， 1969)^{4)}$ は, 砂の粒子状態の解明に統計 力学的な手法を導入して砂の力学特性を求めた。すなわ ち砂の力学特性を支配するものは砂の間げき比とその分 布であるとして，砂を間げき比を確率変量とする相空間 と考え, このような状態確率をもつ体系に扮いて外部仕 事が内部エントロピーの生成になるときを砂の降伏条件 として, 降伏時における力学特性を求め, またエントロ ピーの推移に対応する砂の状態変化を考察した。

上述の Newland and Allely や Rowe の研究結果に は実際の砂の特性と十分に一致しないところがあるが, その理由收実際の砂にみられるような粒子構成における 不規則性が導入されていないためと思われる。

その後，村山・松岡 $(1970 ， 1971 ， 1973)^{5)}$ は，さき に筆者が確率変量に採用した内部摩擦の最大稼劺面に対 する粒子接面の方向角や粒子間力を, 各種径の丸捧を混 合した集合体やその他の粒子からなる試料をせん断変形 をさせた状態で実測し，その実測結果を基礎にして砂の 応力・ひずみ特性を誘導した。これは粒子レベルでの微 視的実測をもとにした一つの特性式であって, 実験事実 と合致する部分も少なくないが, 実験条件における一般 性や確率変量の見方についていくらか十分と思和れない 点があるのでなお検討したいと思っている。

\section{（3）解の方針}

砂は，種々の形状・寸法をもつあまり微小でない独立 した鈗物粒子が不規則配置に構成された集合体である。 また乾燥砂や水で飽和した砂では, 不飽和砂のように粒 子間に水の表面張力が作用しないから, 粒子間に働く力 は, 外力と自重によって粒子相互の接触点に発生する圧 力と摩擦力のみである。

本文では，さきに発表した報告1) と同様に，乾燥砂や 飽和砂のような粘着力のない砂を対象とし, 砂は形, 大 きさ，配置が at random な摩擦性粒子の集合体すなわ ち摩擦性粒子の random assembly であるとした。ゆえ に粒子どうしの接点の方向や接点に作用する粒子間力の 大きさ，方向も at random となり，さらに粒子の挙動 もまた at random となる。

このような摩擦性粒子の random assembly 前提と した砂の挙動を解明するには確率論的な考察が必要であ るので, 統計力学的な手法を導入することとした。さら にこれに用いる確摔変量の選択は解の目標に対してきわ めて重要でまるが，せん断挙動の解析には粒子の形，大 きさに無関係な量が便利であると考えて，粒子相互が滑 動するときに滑動点となる接点すなわち滑動接点におけ る次の $2 つ の$ 無次元量を採択した。 $\beta_{i}$ : 滑動接点に作用 する粒子間力の基準面よりの方向角（添字 $i$ は個々の粒 子の意),$\theta_{i}$ : 滑動接点にお污る滑動面の基準面よりの 方向角。また基準面としては任意のものが用いられて差 支えないが，ここでは 3. (2) に後述する内部摩摖の最大 稼働面を採用した。

本文では，上述のように粒子の移動機構を基礎にして 粘着力のない砂に平均有効主応力一定のもとで偏差応力 を与えたときの応力・ひずみ特性を解明するが，それに は筆者がさきに発表した粒子間力と粒子移動に対する統 計力学的な力法1)をさらに補足・発展させる形でのべる こととする。

\section{2. 砂の弾性状態とその実例}

\section{（1）砂の弾性状態}

通常弾性とは，(a）載荷・除荷のいずれの過程でも Hoolse の法則が成立し，(b) したがって除荷時には残 留ひずみがないこ上をいう。しかし砂の場合には加圧時 と減圧時の応力・ひずみ曲線は一般に一致せず，(a) の 条件は満足さ机ない。そこで砂の場合には (b) の条件 をみそせば弾性的であるということにする。 


\section{（2）弾性状態の砂の実例}

このような砂の弾性状態は砂のくり返し排水三軸圧縮 試験によってつくることができる。その一例を図一1に 示す。三軸圧縮試験においては軸圧 $\sigma_{1}$, 側圧 $\sigma_{2}, \sigma_{3}$ (い ずれも有効応力表示) の関係は $\sigma_{1}>\sigma_{2}=\sigma_{3}$ である。 図一1 注平均有効主応力 $\sigma_{m}\left(=\left(\sigma_{1}+2 \sigma_{3}\right) / 3\right)$ をつねに 一定值 $4 \mathrm{~kg} / \mathrm{cm}^{2}$ に保ち, 偏差応力 $\left(\sigma_{1}-\sigma_{3}\right)$ のみを $0 \sim 4.5 \mathrm{~kg} / \mathrm{cm}^{2}$ の範囲にくり返したときの軸ひずみ $\varepsilon_{1}$ と 偏差応力 $\left(\sigma_{1}-\sigma_{3}\right)$ の関係で, くり返し回数 $n$ が $n=23$ にいたったとき残留ひずみがみとめられなくなり弾性状 態に到達したものとしている。

図一1 の実験に用いた砂は角ばった粒形のもので, 真 比重は 2.73 , 均等係数は 1.85 である。試験前の粒径加 積曲線（図一2 (a)） は試験後も変化がみられなかった ので成形中および試験中に粒子が破砕されたおそれはな い。供試体は高さ約 $8 \mathrm{~cm}$, 直径約 $3.5 \mathrm{~cm}$ の円柱 状に 成形用モールドを介して水中で充填, 締固めをかるく行 い, ゴムスリーブ中に $50 \mathrm{mmHg}$ の真空をかけつつ試験 機内に飽和状態でセットした。セット時の初期間げき比 は 0.75 であった。な㧍試験では, 応力, 軸方向変位を 測定した。

\section{（3）実験結果}

図一1 の実験結果から次の特性がみとめられる。

(a) 残留ひずみ: 各一対の加圧曲線と減圧曲線は hysteresis loop を作り, 減圧して主応力差を再びゼ口 にもどすと残留ひずみが残るが, 残留ひずみは載荷回数 $n$ とともに減少する。軸方向の残留圧縮変位 $\Delta h_{n}$ とく り返し回数 $n$ との関係は図-2 (b) のようである。この 試験では $n=23$ 回に達すると残留ひずみは認められなく なり, $n$ をこれ以上増加しても hysteresis loop は同一 経路を反復するのみとなったので, 前述のように $n=23$ において砂は弾性状態に達したものとみとめた。このと きの加圧曲線はほぼ直線となり直線 $\mathrm{AB}$ で示される。

(b) 加圧曲線：加圧曲線の様相は 1 回目と 2 回目と では図のようにかなり異なる。2 回目以後の加圧曲線は 偏差応力 $\left(\sigma_{1}-\sigma_{3}\right)$ の小さい間は直線に近いが，( $\sigma_{1}-$ $\sigma_{3}$ ）が大きくなるにつれて曲線に移行する。上述の直線 に近い部分の長さは, くり返し回数 $n$ とともに長くな り, 終局的には $n=23$ の場合にみられるように, 加圧 曲線の全区間 $\mathrm{AB}$ がほぼ直線となる。

（c）減圧曲線：減圧曲線は加圧曲線と一致せず曲線 形をなすが, 各減圧曲線はほとんど同形でかつ互いに平 行である。

上述の弾性状態時の砂の弾性 係数は, 図一1 の直線 $\mathrm{AB}$ の傾斜角の正切で与えられ，この值はせいぜい $10^{3}$
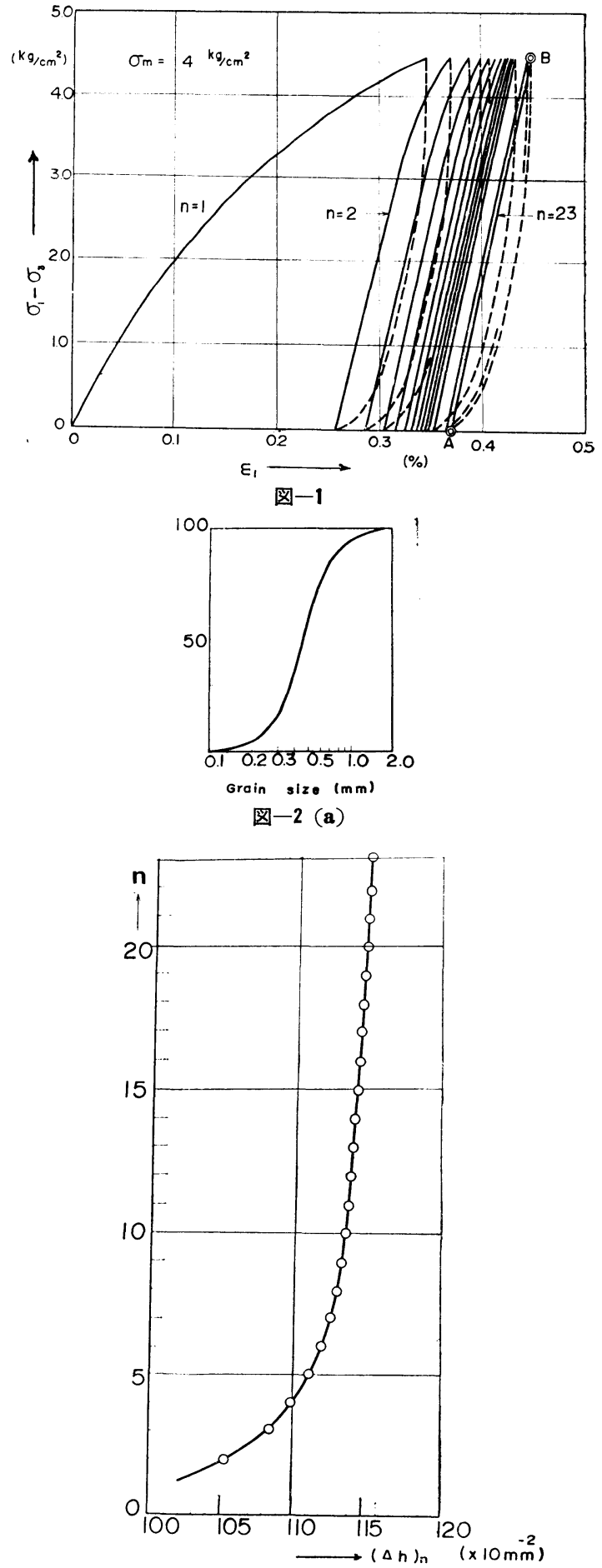

図一2(b)

$\mathrm{kg} / \mathrm{cm}^{2}$ のオーダーである。これは砂粒子の等方圧を受 けたときの弾性係数の $10^{6} \mathrm{~kg} / \mathrm{cm}^{2}$ のオーダー6)に比し て非常に小さい。ゆえに砂全体すなわち砂質土としての 弾性沙砂粒子自身の弾性とは別な原因によるものと考え 
ねばならない。

\section{3. 砂質土における粒子間力}

\section{（1）砂粒子相互の接触状況}

水で飽和した砂質土を非排水状態にして, その表面に

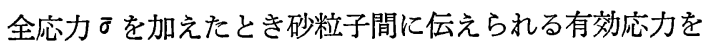
$\sigma$, 間げき水圧を $u$, 単位面積当りの粒子相互の 接触面 積の和を $A_{c}$ とすると次式が成立つ。

$$
\bar{\sigma}=\sigma+\left(1-A_{c}\right) \cdot u
$$

一方実験によると, 実際の土では砂質土でも粘質土で もるは，高度の近似をもって次式で示されるといわれて いる?。

$$
\bar{\sigma}=\sigma+u
$$

ゆえに $A_{c}$ の大きさはきわめて小さく $A_{c} \doteqdot 0$ と仮定 しても差支えない。また Bishop および Eldin (1950) ${ }^{8)}$ によれば, 粗粒土 (coarse grain soil) が圧接により破 壊した場合でも破砕による $A_{c}$ の増大は, $\left(1-A_{c}\right)$ の 中で $A_{c}$ が占める率は $1 \%$ にもならないとのべている。

以上のことから, 砂は乾燥時にも, また不飽和時にも 粒子相互の接触は飽和時と同様に点で接していると考え ても差支えないであろう。

\section{（2）砂粒子接点の活動}

砂が有効主応力 $\sigma_{1}, \sigma_{2}, \sigma_{3}$ （ただし $\sigma_{1}>\sigma_{2}=\sigma_{3}$ ）によ って三軸圧縮を受けたとき，砂全体としてみたとき砂粒 子のせん断応力による相対移動が最大に活発化する面 は, その面への有効垂直応力 $\sigma$ とせん断応力 $\tau$ とが, $\tan ^{-1}(\tau / \sigma)$ を, したがって $(\tau / \sigma)$ を最大にする方向の面 である。 $\tan ^{-1}(\tau / \sigma)_{\max }$ を $\phi$ とすれば， $\phi$ は図一3 (a) のように Mohr の応力円への原点からの切線が $\sigma$-朝と なす角で与えられる。ゆえに $\sigma_{1}$ と $\sigma_{3}$ を含む面内に対 しては，

$$
\begin{aligned}
\phi & =\tan ^{-1}\left(\frac{\tau}{\sigma}\right)_{\max }=\sin ^{-1}\left(\frac{\mathrm{AB}}{\mathrm{OA}}\right) \\
& =\sin ^{-1}\left(\frac{\sigma_{1}-\sigma_{3}}{\sigma_{1}+\sigma_{3}}\right) \ldots \ldots \ldots \ldots \ldots \ldots \ldots \ldots \ldots \ldots \ldots \ldots \ldots \ldots
\end{aligned}
$$

またこの $(\tau / \sigma)_{\max }$-面は図一3 (b) の $(\tau / \sigma)_{\max }$-面のよ うに最大主応力面 I-I と $\{(\pi / 4)+(\phi / 2)\}$ の傾きをなし ている。

ここに角 $\phi$ は, 三軸方向に有効主応力 $\left(\sigma_{1}>\sigma_{2}=\sigma_{3}\right)$ をうけた砂が $(\tau / \sigma)_{\max }$ 一面にそってせん断変形をすると き, 砂のもつ内部摩擦角のうちこの面で稼働している内 部摩擦角であって, この $\phi$ を稼働内部摩擦角 (mobilized internal frictional angle) といい, また $(\tau / \sigma)_{\text {max }^{-}}$ 面は, せん断応力による粒子の相対移動が最も活発化す る面であり，また内部摩擦の稼働も最大になる面である

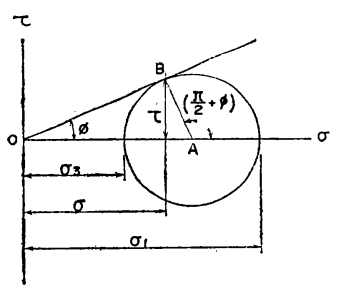

(a)

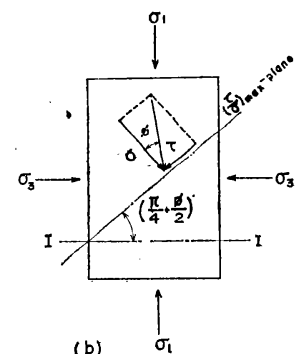

図一3
から, $(\tau / \sigma)_{\max }$-面を内部摩擦の最大稼働面 (plane of maximum mobilization) ということにする。

通常の三軸圧縮試験では, 有効主応力は $\sigma_{1}>\sigma_{2}=\sigma_{3}$ で あるから， $\sigma_{1}$ と $\sigma_{2}$ を含む面内でも式 (1) と同様の関 係や $(\tau / \sigma)_{\max }$-面が存在するが， $\sigma_{2}$ と $\sigma_{3}$ を含む面内で は $\sigma_{2}=\sigma_{3}$ であるからこのような関係や $(\tau / \sigma)_{\max }$ 面は 存在しない。

上述のように，せん断応力によって稼働 (mobilized) された砂粒子は $(\tau / \sigma)_{\max }$-面にそって最も多く集結して いるが，( $\tau / \sigma)_{\max }$-面にそって存在する稼働粒子 個 々の 移動方向を微視的にみれば，それらの粒子はそれぞれの 隣接粒子の表面にそっておのおの独自の方向にすべりな
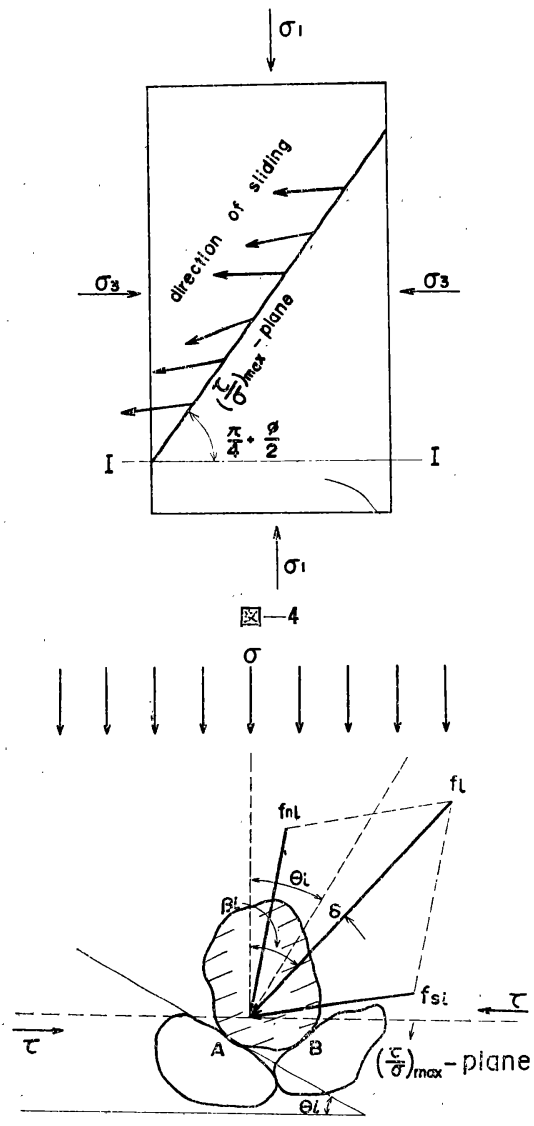

図-5 
がら移動する（図一4 参照）。

いま図一5 のように $(\tau / \sigma)_{\max }$ 一面にそって存在する一 個の砂粒子（たとえば斜線をつけた粒子）に注目しよ う。この粒子は $(\tau / \sigma)_{\max }$ 一面の上方にある隣接粒子の接 点群を通じて合力 $f_{i}$ を受け, $(\tau / \sigma)_{\max }$-面以下では 2 接 点 $\mathrm{A}, \mathrm{B}$ によって外力 $f_{i}$ を支持している。 $f_{i}$ が $(\tau /$ $\sigma)_{\max }$ 一面の法線となす角を $\beta_{i}$ とし，これを粒子間力の 方向角ということにする。 $f_{i}, \beta_{i}$ は粒子ごとで異なり一 定ではない。なお添字 $i$ は個々の粒子 (individual particle）の值を意味するものとする。

有効垂直応力 $\sigma$ を一定に保ち, せん断応力 $\tau$ を増加し ていくと接点 $\mathrm{B}$ における接触圧法減少し，ついに接点 $\mathrm{B}$ は接触を断ち，粒子は接点Aのみで下方粒子に接しなが ら左方にすべり動くにいたる。ここで下方粒子表面は滑 動接点 $\mathrm{A}$ の摩擦斜面となる。この斜面の $(\tau / \sigma)_{\max }$-面に 対し, 滑動接点の移動方向に測った傾斜角を $\theta_{i}$ と記し, これを接点方向角ということにする。角 $\theta_{i}$ の值もまた 粒子ごとでそれぞれ異なり一定ではない。摩擦斜面に㧍 ける摩擦角すなわち 砂粒子相互の摩摖角を $\delta_{i}$ とする。 摩擦角 $\delta_{i}$ 法砬子の鉣物成分, 表面の粗らさなどによ っていくらか不同があるであろうが，滑動または不動の 粒子群についてみれば，それら群に属する粒子は at random に選ばれたものであるから，各群の粒子数が多 いときは, 各群の粒子の $\delta_{i}$ の平均值 $\delta$ は粒子全体の $\delta_{i}$ の平均值 $\delta$ に等しい。ゆえにここでは平均的にみて 各接点とも一ように $\delta$ であると仮定する。

上記のように， $\beta_{i}, \theta_{i}$ は各接点ごとに at random の

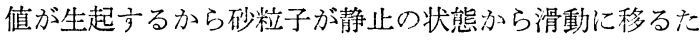
めの条件法次式で与えられる。

$$
\theta_{i}-\beta_{i}+\delta \equiv y \leq 0
$$

$\beta_{i}$ ならびに $\theta_{i}$ の值は砂とその粒子状態が定まれば, ある確率分布をなすものと推定される。砂の単位面積中 にある粒子の数を $N$ とし， $\beta_{i}, \theta_{i}$ の平均值をそれぞれ $\beta, \theta$ とすれば,

$$
\beta=\frac{1}{N} \sum^{N} \beta_{i}, \theta=\frac{1}{N} \sum^{N} \theta_{i}
$$

面積の単位を粒子の大きさに比べで十分大きくして, $N$

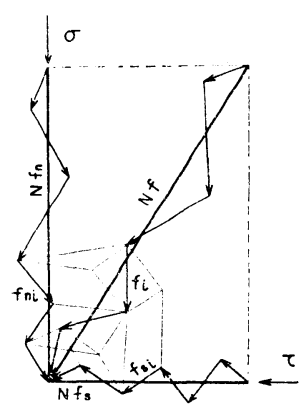

图-6
芝十分大きくとれば，均質な 砂では $\beta, \theta$ の值はどこの単 位面積でも一定值となる。

砂全体を巨視的にみたと き, $(\tau / \sigma)_{\max }$ 面には図一3(a) のように有效西直応力 $\sigma$ とせ 儿断応力 $\tau$ とが作用している が，個々の粒子の滑動接点に 作用する力 $f_{i}$ は前述のよう にその大きさ，方向ともに接
点ごとに区々である。いま $f_{i}$ を $\sigma$ に起因する力 $f_{n i}$ と $\tau$ に起因する力 $f_{s i}$ とに分解する。 $f_{n i}, f_{s i}$ も各粒子

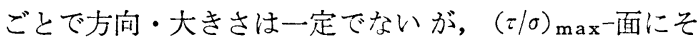
う単位面積中の多数の粒子の各 $f_{n i}$ と $f_{s i}$ を図一6の ようにベクトル的に順次加え合わせた合力は, 面積の単 位を大きくして，N を十分大きくとれば，それぞれ $\sigma$ ， て と大きさ・方向ともに一致するはずである。いまこれ らのベクトルの合力を $N$ で除した平均值を $f_{n}, f_{s}$ と すれば， $f_{n}, f_{s}$ はそれぞれ $\sigma$ または $\tau$ と方向を同じく し，かつそれらの大きさはそれぞれ $\sigma$ また汶ての $1 / N$ となる。すなわち $(\tau / \sigma)_{\text {max }}$ 一面に対して

$$
\left.\begin{array}{l}
f_{n}=\frac{1}{N} \sum f_{n i} \cdot \cos \left(\widehat{f_{n i}} \sigma\right)=\frac{\sigma}{N} \\
f_{s}=\frac{1}{N} \sum f_{s i} \cdot \cos \left(\widehat{f_{i s}} \tau\right)=\frac{\tau}{N}
\end{array}\right\}
$$

また $N$ が十分大きくとれていれば，各粒子に憉く $f_{n i}$ と $f_{s i}$ の合力 $f_{i}$ の大きさ, 方向は, $f_{n}$ と $f_{s}$ の 合力 $f$ の左右に均等凉確率で対称に分布するとみて差 支えないであろう。そうすれば個々の $f_{i}$ が $(\tau / \sigma)_{\max }$ 面の法線となす角すなわち $f_{i}$ の方向角 $\beta_{i}$ の平均值 $\beta$ は $f$ が $(\tau / \sigma)_{\max }$ 一面の法線とな寸角に等しくなるから，

$$
\tan ^{-1}\left(\frac{f_{s}}{f_{n}}\right)=\beta
$$

上式と式（1）（4）上り

$$
\beta=\tan ^{-1}\left(\frac{f_{s}}{f_{n}}\right)=\tan ^{-1}\left(\frac{\tau}{\sigma}\right)_{\max }=\phi
$$

砂が弹性状態にある場合は，その偏差応力ーひずみ関 係が固定した hysteresis loop をえがくことおよび加圧 曲線に塑性的な様相がみられないことなどから，その粒 子構造注外力に封して安定な状態にあることがみとめら れる。ゆえに砂が弾性状態にある場合は，粒子の一部が 偏莣忘力によって隣接粒子の摩擦斜面にそって移動する が, 岁る距離だけ滑動するとその摩擦斜面の途中で停止 し, 斜面頂点学越えてまでも次の安定位置に移動するよ うな活性化 (activate) した移動溌生しないと考えら れる。ついでここで偏差応力を除荷すれば，滑動した粒 子はその停止位置より当初の位置に復帰し, 弾性状態で は載荷と除荷によっては除荷時の眇の粒子構造には変化 が生じないこととなる。な捈荷のときの関係は，

$$
\beta_{i}+\delta<\theta_{i} \text {. }
$$

このようにして弾性状態に㧈ける砂の载荷と除荷過程 にみられる偏差応力ーひずる曲線の可逆的な特性は上述 のような䊀子の同一傾斜角の摩擦斜面内の往復運動によ って理解することができる。ゆえに砂が弾性状態にあ場 合には，粘子自身の形状が破砕などによって変化しない 限り粒子配列は偏差応力によって不变であり，したがっ て粒子の接点方向角 $\theta_{i}$ の礁率分布も倘差応力によって 変化しないこととなる。 


\section{4. 砂粒子の滑動確率}

前述のように各砂粒子の滑動接点に抢ける角 $\beta_{i}, \theta_{i}$ の 值は粒子ごとで異なり，まったく at random であるが 粒子全体についてみればある確率分布をしているとみら れる。特に砂が弾性状態にある場合には角 $\beta_{i}, \theta_{i}$ それぞ れは平均值 $\beta, \theta$ に近いものほど多く，それを中央值と してその前後に両側有限の対称分布をすると考えられ る。

これらの確率分布を示す関数には種々のものが考えら れるが，ここでは計算の便宜上，両側有限ではないが， 近似的に正規確率分布 (Gaussian distribution) で近似 できると仮定する。すなわち $\beta_{i}$ (これを $x_{1}$ と記す）に ついては, $m_{1}(=\beta)$ を平均值とする正規確率関数 $f\left(x_{1}\right)$ をまた $\left(\theta_{i}+\delta\right)\left(x_{2}\right.$ と記す）については $m_{2}(=\theta+\delta)$ を平均值とする正規確率関数 $\varphi\left(x_{2}\right)$ を仮定する。すな わち

$$
\begin{aligned}
f\left(x_{1}\right)= & \frac{1}{\sqrt{2 \pi} \rho_{1}} \exp \left\{-\frac{\left(x_{1}-m_{1}\right)^{2}}{2 \rho_{1}{ }^{2}}\right\} \\
& \equiv N\left(m_{1},{\rho_{1}}^{2}\right) \\
\varphi\left(x_{2}\right) & =\frac{1}{\sqrt{2 \pi} \rho_{2}} \exp \left\{-\frac{\left(x_{2}-m_{2}\right)^{2}}{2 \rho_{2}{ }^{2}}\right\} \\
& \equiv N\left(m_{2}, \rho_{2}{ }^{2}\right)
\end{aligned}
$$

ここに $N\left(\right.$ ） は正規確率関数を示す記号， $\rho_{1}, \rho_{2}$ は標 準偏差であり,また

$$
\left.\begin{array}{ll}
x_{1}=\beta_{i}, & x_{2}=\theta_{i}+\delta \\
m_{1}=\beta, & m_{2}=\theta+\delta
\end{array}\right\}
$$

上式を図示すれば 図一7 (a) のようになる。なお標準偏 差 $\rho_{1}, \rho_{2}$ (または分散 $\rho_{1}{ }^{2}, \rho_{2}{ }^{2}$ ) は砂粒子の配列状 態 と 外圧の載荷条件に関係するとみられる。

前述のように，砂質土が弾性状態にある場合では平均 有効主応力 $\sigma_{m}$ を一定に保ちつつ偏差応力を加除しても 砂粒子は隣接砂粒子の頂点を越えて他の安定位置に移動

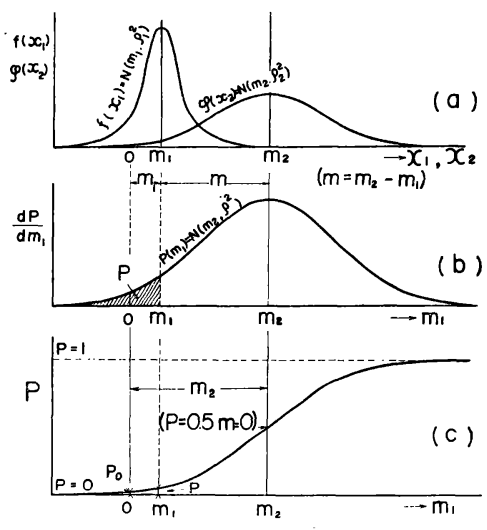

図一7
しないから，粒子相互の配列構造は常に不変である。ゆ えに個々の砂粒子に対する $x_{2}\left(=\theta_{i}+\delta\right)$ は粒子ごとに異 なっていても,全体としての分布 $\varphi\left(x_{2}\right)$ したがって $m_{2}$, $\rho_{2}$ は常に一定である。一方 $x_{1}\left(=\beta_{i}\right)$ は外圧の大きさで かわり，その平均值 $m_{1}(=\beta)$ は式 (5) によって一義的 に与えられるが, $x_{1}$ の分布形は弹性状態においては粒 子の配列構造がかわらないから外圧の載荷条件が一定で あれば外圧の大きさに無関係に一定とみられる。したが って標準偏差 $\rho_{1}$ は一定となる。

砂粒子が偏差応力によって滑動する条件 は式 (2) で 与えられ，これを式 (8) の記号でかけば次式となる。

$$
x_{2}-x_{1}=y \leq 0
$$

$x_{1}, x_{2}$ は互いに独立 (independent) な正規確率変数 であるから, それらの一次結合であるyの確率密度関数 $p(y)$ は次式のように, $m$ を平均值, $\rho$ を標準偏差とす る正規確率関数で与えられる。

$$
\begin{aligned}
& \quad p(y)=\frac{1}{\sqrt{2 \pi} \rho} \exp \left\{-\frac{(y-m)^{2}}{2 \rho^{2}}\right\} \equiv \frac{d P}{d y} \\
& \text { ここに } \rho=\sqrt{{\rho_{1}{ }^{2}+\rho_{2}^{2}}^{2}}, m=m_{2}-m_{1}=\theta-\beta+\delta
\end{aligned}
$$

ゆえに砂質土中の $(\tau / \sigma)_{\text {max }}$ 一面にそって存在する全砂 粒子のうち滑動粒子が発生する確率 $P$ は式 (10) の確 率分布曲線 $p(y)$ の $y \leqq 0$ の範囲の面積によって与え られる。ここに $P$ を滑動確率 (probability of sliding particles) といらことにする。P の值は

$$
P=\int_{-\infty}^{0} p(y) d y
$$

いま $(y-m) / \rho=t$ とおけば,

$$
d y / \rho=d t,
$$

$y=0$ では $t=-m / \rho, y=-\infty$ では $t=-\infty$,

$$
\begin{aligned}
& \therefore P=\frac{1}{\sqrt{2 \pi}} \int_{-\infty}^{-m / \rho} e^{-t^{2} / 2} d t \equiv F\left(-\frac{m}{\rho}\right) \\
& \text { ここに } \quad t=(y-m) / \rho
\end{aligned}
$$

$F(-m / \rho)$ は $N(0,1) \equiv(1 / \sqrt{2 \pi}) \cdot \exp \left(-t^{2} / 2\right)$ で示さ れる 1 単位の標準偏差をもつ正規確率関数の累積分布曲 線で示されるものであって, その数值は正規確率関数の 確率積分表で求められる。

次に, $m_{1}$ の増加による $P$ の変化をみるため $d P / d m_{1}$ を検討する。 $t$ は $m_{1}$ の值のいかんにかかわらず任意の 值をとることができるから， $t$ と $m_{1}$ とは互いに独立な 変数である。ただし積分範囲の上限 $m$ は $m_{1}$ の関数で あるから， $d P / d m_{1}$ は，

$$
\begin{aligned}
\frac{d P}{d m_{1}} & =\frac{d}{d m_{1}} \int_{-\infty}^{-m / \rho} \frac{1}{\sqrt{2 \pi}} e^{-t^{2} / 2} d t \\
& =\frac{1}{\sqrt{2 \pi}}\left[e^{-t^{2} / 2}\right]_{t=-m / \rho} \cdot \frac{d}{d m_{1}}\left(\frac{-m}{\rho}\right)
\end{aligned}
$$




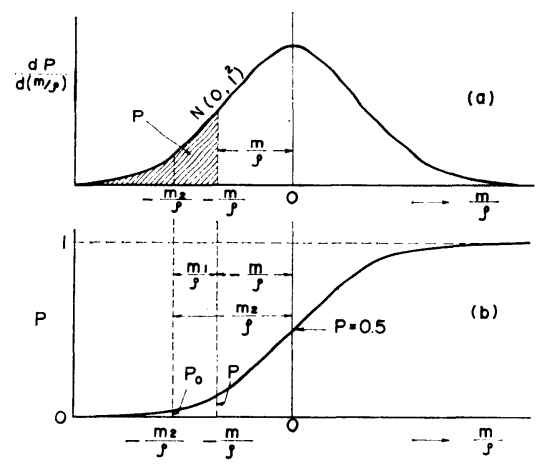

図-8

$$
=\frac{1}{\sqrt{2 \pi}} \cdot \exp \left\{-\frac{m^{2}}{2 \rho^{2}}\right\} \cdot \frac{d}{d m_{1}}\left(\frac{-m}{\rho}\right)
$$

$m=-\left(m_{1}-m_{2}\right)$ であるから

$$
\frac{d P}{d m_{1}}=\frac{1}{\sqrt{2 \pi} \cdot \rho} \cdot \exp \left\{\frac{-\left(m_{1}-m_{2}\right)^{2}}{2 \rho^{2}}\right\} \equiv p\left(m_{1}\right)
$$

ゆえに弾性状態にある砂に $m_{1}$ で示される偏差応力を 載荷することによって生ずる滑動確率 $P$ は

$$
P=\frac{1}{\sqrt{ } 2 \pi \rho} \int_{-\infty}^{m_{1}} \exp \left\{-\frac{\left(m_{1}-m_{2}\right)^{2}}{2 \rho^{2}}\right\} d m_{1}
$$

式 (13)，(14）の $P$ はそれぞれ式 (10)，(11) の $P$ の $m_{1}$ による変化を明らかにしたものである。すなわち式 (13)，(14）は $m_{2}$ を平均值， $\rho$ を標準偏差， $m_{1}$ を確 率変数とする正規確率関数で示したもので, それぞれ 図一7の (b), (c) のようになる。

また式 (13)，(14）の確率変数 $m_{1}$ を $m / \rho$ にかえれ ば標準偏差 $=1$ をもつ次式となり,これらを図示すると それぞれ図一8 (a),(b) のようになる。ここに $m$ は, $m=m_{2}-m_{1}$ 。これらの数值は $m / \rho$ を変数とみて正規確 率関数の数表から求めることがでる。

$$
\left.\begin{array}{rl}
\frac{d P}{d(m / \rho)} & =\frac{1}{\sqrt{2 \pi}} \exp \left\{-\frac{1}{2}\left(\frac{m}{\rho}\right)^{2}\right\} \\
\equiv g\left(-\frac{m}{\rho}\right) \\
P=\frac{1}{\sqrt{2 \pi}} \int_{-\infty}^{-m / \rho} \exp \left\{-\frac{1}{2}\left(\frac{m}{\rho}\right)^{2}\right\} d\left(\frac{m}{\rho}\right) \\
\equiv F\left(-\frac{m}{\rho}\right)
\end{array}\right\}
$$

\section{5. 弾性状態にある砂のせん断ひずみ}

前節 3.では図一5 において接点Aを例にとり，これ が滑動接点になる経過をのべたが，このような滑動接点 が形成されるためには砂にわずかの偏差応力が加えられ ることが必要である。偏差応力の載荷初期に最初の滑動 接点が砂中に形成されるために要する偏差応力の大きさ

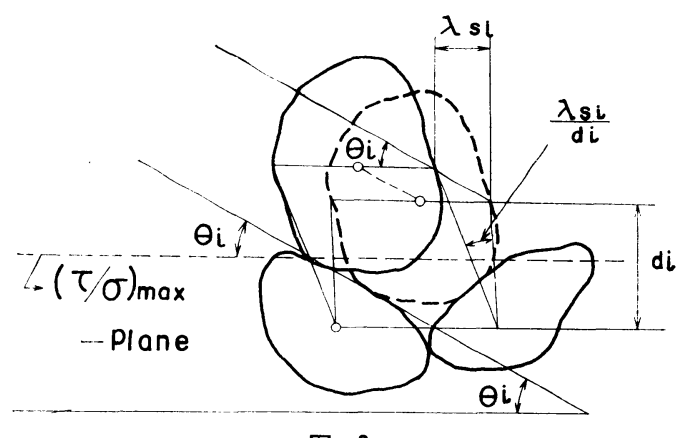

図一9

を粒子間力の方向角であらわして $m_{0}\left(=\beta_{0}\right)$ とする。式 (15) は $m_{1}$ で示される偏差応力を砂に加えたときの粒 子の滑動確率 $P$ を与えるから, 粒子の滑動開始時の粒 子の滑動確率を $P_{0}$ とすると, $P_{0}$ は $m_{1}=m_{0}$ を式 (15) に代入して求められる。しかし $m_{0}$ はきわめて小さい量 であるから，近似的に $m_{0} \doteqdot 0$ (等方圧状態) とおいて も大差がない。ゆえに $P_{0}$ は

$$
P_{0}=F\left(-\frac{m_{2}}{\rho}\right)
$$

ゆえに等方圧状態にあった砂に $m_{1}$ で示す偏差応力を 加えたときの滑動確率の増加は,

$$
P-P_{0}=F\left(-\frac{m}{\rho}\right)-F\left(-\frac{m_{2}}{\rho}\right)
$$

偏差応力によって粒子の一部は隣接粒子表面を滑動す るが, 砂が弾性状態にある間は隣接粒子の斜面頂点を越 えてまでは移動しないから, 粒子の移動距離には限度が ある。このときある滑動粒子について $(\tau / \sigma)_{\max }$ 一面の方 向にはかった移動距離を $\lambda_{s i}$, その粒子の隣接粒子との 間の距離を $d_{i}$ とすれば，この粒子の隣接粒子に対する 角変位は図一9 のように $\lambda_{s i} / d_{i}$ となる。滑動粒子の個々 の移動距離や粒子間距離はそれぞれの粒子の粒径や配列 などが不同であるから一定ではないが, 粒子の滑動は全 粒子のらちから at random に生起するから, 滑動粒子 群の各 $\lambda_{s i} / d_{i}$ の平均值は, かりに全粒子が滑動するとし た場合の全粒子の $\lambda_{s i} / d_{i}$ の平均值に等しいはずである。 ゆえにこの砂の全粒子についての粒子間距離の平均を $d$, 滑動する場合の粒子移動距離の平均を $\lambda_{s}$ とすると, 滑動粒子の平均角変位は $\lambda_{s} / d$ となる。

$$
\frac{\lambda_{s}}{d}=\frac{1}{N} \sum^{N} \frac{\lambda_{s i}}{d_{i}}
$$

角変位 $\lambda_{s} / d$ は砂粒子の形状, 寸法, 配列などできま るが, 平均有効主応力や偏差応力の大きさには無関係と みられる。また 1 個の滑動粒子に生じる平均角変位 $\lambda_{s} / d$ は, 砂全体に生じる（ $\tau / \sigma)_{\max }$ 一面におけるせん断ひずみ $r_{\beta}$ に $c \cdot \lambda_{s} / d$ だけの寄与を与えるものとする。ここに $c$ は寄与係数 (contribution factor) であって, 粒子の 滑動が全粒子に対して at random に生起することか 
ら，cは一定の定数とおくことができる。

砂の単位面積中には $N$ 個の粒子があり，また等方圧 のもとにあった砂に $m_{1}$ で示される偏差応力を加えたた めに生ずる滑動確率の増加は式 (17) のように（P$\left.P_{0}\right)$ であるから, これら滑動粒子の角変位の結果, 砂に 生ずる $(\tau / \sigma)_{\max }$-面のせん断ひずみ $\gamma_{\beta}$ は次式で与えら れる。

$$
\gamma_{\beta}=\left(c \cdot r_{s} / d\right)\left(P-P_{0}\right) N
$$

\section{6. 弾性状態にある砂のダイラタンシー}

粒子が隣接粒子の表面を滑動すると，図一9 のように 滑動粒子は $(\tau / \sigma)_{\max }$ 一面から角 $\theta_{i}$ だけ上方にそれて動 くから， 1 個の粒子の滑動によって粒子間隔 $d_{i}$ は（ $\tau$ / $\sigma)_{\max }$-面に垂直な方向に $\lambda_{s i} \cdot \tan \theta_{i} / d_{i}$ の割合で拡がる。 このような 1 粒子の垂直方向の移動成分が, 砂全体の（ $\tau$ ) $\sigma)_{\max }$-面と直角な方向の膨張ひずみ $-\varepsilon_{n}\left(\varepsilon_{n}\right.$ は圧縮ひ ずみを正で示す）に寄与する効果は，この滑動粒子がせ 几断ひずみ $\gamma_{\beta}$ に寄与する効果之同一と考えられるか $ら ， \lambda_{i}, d_{i}$ に関する式 (18) の関係および式 (19) に用 いた寄与係数 $c$ がここにも適用できる。ゆえに滑動確率 が $P$ から $\Delta P$ だけ增加したときの $-\varepsilon_{n}$ の增加を $-\Delta \varepsilon_{n}$ とすると， $-\Delta \varepsilon_{n}$ は，

$$
\begin{aligned}
-\Delta \varepsilon_{n} & =\left(c \cdot \lambda_{s} / d^{t}\right) \sum_{N P}^{N(P+\Delta P)} \tan \theta_{i} \\
& =\left(c \cdot \lambda_{s} / d\right) N \cdot \Delta P \cdot \tan \theta_{e}
\end{aligned}
$$

ここに $\tan \theta_{e}$ は全粒子接点のうち $P$ において生ずる滑 動接点の $\tan \theta_{i}$ の平均値である。 $\theta_{i}$ は通常小さいから $\theta_{e}$ は $\theta_{i}$ の平均值とすることができる。すなわち

$$
\theta_{e} \doteqdot \sum_{N P}^{N(P+\Delta P)} \theta_{i} /(N \cdot \Delta P)
$$

式（19）から，Pが $\Delta P$ 増加したことによるケ反の増加 $\Delta \gamma_{\beta}$ は,

$$
\Delta r_{\beta}=\left(c \lambda_{s} / d\right) N \cdot \Delta P
$$

ゆえに上述の $-\Delta \varepsilon_{n}$ と $\Delta \gamma_{\beta}$ の関係を微分形で記すと

$$
-d \varepsilon_{n}=\tan \theta_{e} \cdot d \gamma_{\beta}
$$

次化 $\theta_{e}$ を求めよう。いま式 (8)の $x_{1}, x_{2}$ を次式の ような $t_{1}, t_{2}$ で示す。

$$
t_{1}=\left(x_{1}-m_{1}\right) / \rho_{1}, \quad t_{2}=\left(x_{2}-m_{2}\right) / \rho_{2} \text {. }
$$

式（21）を式 (2)，(7) に代入するとそれぞれ

$$
\begin{aligned}
& t_{2}=\frac{\rho_{1}}{\rho_{2}} t_{1}-\frac{m-y}{\rho_{2}} \\
& f\left(x_{1}\right) \cdot d x_{1}=\frac{1}{\sqrt{2 \pi}} \cdot \exp \left(-\frac{t_{1}{ }^{2}}{2}\right) d t_{1} \equiv Z_{1} \\
& \varphi\left(x_{2}\right) \cdot d x_{2}=\frac{1}{\sqrt{2} \pi} \cdot \exp \left(-\frac{t_{2}{ }^{2}}{2}\right) d t_{2} \equiv Z_{2}
\end{aligned}
$$

$t_{1}, t_{2}$ を同一縮尺の水平な直交 2 軸とし, それらに直交

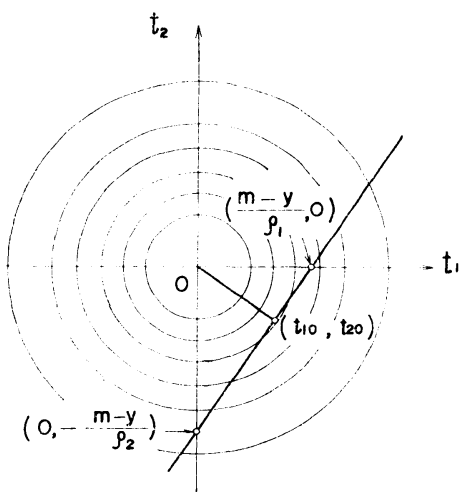

図-10

する鉛直軸を $Z$ 軸とする。 $t_{1}, t_{2}$ には互いに相関がな く，また $Z_{1}=Z_{2}$ であるから式 (23) をこれら 3 軸にプ ロットすると, $Z\left(=Z_{1}=Z_{2}\right)$ の面は $Z$ 軸に対称な正規 確率曲面となる。ゆえにこの曲面上の等確率線を（ $t_{1}$, $\left.t_{2}\right)$-平面に投影すると図一10のような原点を中心とする 同心円であらわされる。この平面に式 (22) をえがくと 同図の右上りの直線となる。またこの直線を底辺にもつ 鉛直面と磪率曲面との交線は，正規確率曲線に似た極大 点をもつ曲線となり, この極大点の $\left(t_{1}, t_{2}\right)$-面への投影 を座標 $\left(t_{10}, t_{20}\right)$ で示そう。この投影点は, 前記直線上 にあり，またこの投影点と原点 0 とを結ぶ直線は前記直 線と直交しなければならないから，原点と投影点を結ぶ 直線は次式で表わされる。

$$
t_{2}=-\left(\rho_{2} / \rho_{1}\right) t_{1}
$$

ゆえにこの投影点の座標の值は式（22）と式 (24) の 2 直線の交点の座標として次式で与えられる。

$$
t_{10}=\frac{\rho_{1}(m-y)}{\rho^{2}}, \quad t_{20}=-\frac{\rho_{2}(m-y)}{\rho^{2}}
$$

上式の $t_{10}, t_{20}$ はある $y$ の值を満足するような鉛直平 面之 $Z$ 曲面との交線の mode (最確值) を与えるもの である。また $t_{10}, t_{20}$ はそれぞれ $y$ を満足するような $t_{1}-Z$ 面上の $t_{1}$ の分布曲線の mode および $t_{2}-Z$ 面上の $t_{2}$ の分布曲線の mode の值を与えるものとなる。そこでい まこの $y\left(=x_{2}-x_{1}\right)$ を満足するような $x_{1}$-群および $x_{2}$ 群に㧍けるそれぞれの mode の值を $x_{10}, x_{20}$ とすれば, これらはそれぞれ $t_{10}, t_{20}$ に対応するから，式 (25) を 式（21）に代入したときの $x_{1}, x_{2}$ の值として与えられ る。

$$
\left.\begin{array}{l}
x_{10}=\left(m_{1} \rho_{2}{ }^{2}+m_{2} \rho_{1}{ }^{2}-y \rho_{1}^{2}\right) /\left({\rho_{1}}^{2}+\rho_{2}{ }^{2}\right) \\
x_{20}=\left(m_{1} \rho_{2}{ }^{2}+m_{2} \rho_{1}{ }^{2}+y \rho_{2}{ }^{2}\right) /\left(\rho_{1}{ }^{2}+\rho_{2}{ }^{2}\right)
\end{array}\right\}
$$

また $x_{10}, x_{20}$ は $y$ のある值を満たす $x_{1}$-群, $x_{2}$-群の mode であるとともに，それぞれの群における平均值を 与えている。

一方 $m_{1}$ で示される偏差応力をうけている砂におい て， $m_{1}$ を $d m_{1}$ だけ増加するときそれに対応する $y$ の 
変化は, 同一標準偏差をもつ式 (11) と式 (14) の対比 からもわかるように， $y=0$ にある $y$ を $d y$ だけ增加 することに対応している。ゆえに $m_{1}$ に対応する $y$ の 值は $y=0$ である。また式 (26) の $x_{20}$ は，上述のよう に, ある $y$ の值を満足する $x_{2}$-群の平均值であり, $y=$ 0 を満足する $x_{2}$-群の平均值 $x_{20}$ は, はじ的にのべたよ うに $x_{20}=\theta_{e}+\delta$ にほかならない。

ゆえに $\left(\theta_{\boldsymbol{e}}+\delta\right)$ は式 (26) に $y=0$ を代入した次式 で与えられる。

$$
\theta_{e}+\delta=\left(m_{1} \rho_{2}{ }^{2}+m_{2}{\rho_{1}}^{2}\right) /\left({\rho_{1}}^{2}+\rho_{2}{ }^{2}\right)
$$

上式両辺の正切を求めると，

$$
\tan \left(\theta_{e}+\delta\right)=\tan \left\{\left(m_{1} \rho_{2}{ }^{2}+m_{2} \rho_{1}{ }^{2}\right) /\left(\rho_{1}{ }^{2}+\rho_{2}{ }^{2}\right)\right\}
$$

交た上式左辺は 2 角の和の正切であるから， $\tan \left(\theta_{\boldsymbol{e}}+\delta\right)=\left\{1+\tan \left(\theta_{\boldsymbol{e}}+\delta\right) \cdot \tan \delta\right\} \tan \theta_{\boldsymbol{e}}+\tan \delta$ 上式に式 (20)，(27）を代入すると，

$$
\begin{gathered}
\lambda\left(-\frac{d \varepsilon_{n}}{d \gamma_{\beta}}\right)+\tan \delta=\tan \left\{\left(m_{1} \rho_{2}{ }^{2}+m_{2} \rho_{1}^{2}\right) /\right. \\
\left.\left(\rho_{1}{ }^{2}+\rho_{2}{ }^{2}\right)\right\}
\end{gathered}
$$

ここに

$$
\begin{aligned}
& \lambda=1+\tan \left(\theta_{\mathcal{e}}+\delta\right) \cdot \tan \delta, \\
& m_{1}=\beta=\tan ^{-1}(\tau / \sigma)_{\max }, \quad m_{2}=\theta+\delta
\end{aligned}
$$

. は $\theta_{e}$ と $\delta$ の関数であるが, $\theta_{e}$ が通常小さいので $\theta_{e}$ の影響が比較的少ないから, 粒子間摩擦角 $\delta$ に多く関係 し，また $\delta$ 沙が一定であれば一定であるから入は近 似的に一定定数の係数とみなしても大差がない。

\section{7. 接点方向角と粒子間力方向角の分布}

滑動粒子の接点方 向 角 $\theta_{i}$ や粒子間力の方向角 $\beta_{i}$ の 分布は, 前述のような統計力学的手法を土質力学の場に 導入する際, 確率論的な土の物性量の一つとして非常に 重要なものである。しかしあらたな概念の量であるから， この特性に関し必要とする知見は従来まったくみられな い。それゆえここでは, 種々の観点から推論によって考 察を行ってみたが, そのうち弹性状態の砂に対して考え た事項を簡単に提示寸る。なお詳細な説明は, 塑性状態 にある砂の内部機構とも関係があるから, 塑性状態を扱 ら別の機会にゆずることとする。

前述のように, 砂の弾性状態は一定の平均有効主応力 $\sigma_{m}$ のもとで, 一定の偏差応力 $\left(\sigma_{1}-\sigma_{3}\right)$ を砂にくり返し 載荷することで得られ, また弾柱状態に達した砂はこの 偏差応力以下の応力のもとでは粒子の配列構造が不変で あるから，粒子の接点方向角の分布は一定となり，した がって $\theta+\delta\left(=m_{2}\right), \rho_{2}$ も一定となる。一方弾性状態の 砂では, 個々の粒子の粒子間力の大きさは偏差応力の大
きさによって変化するが, 粒子間力の方向角 $\beta_{i}$ の分布 形は粒子間力による粒子の変形係数が無視されるほど小 さく, かつ載荷条件が一定であれば, 偏差応力の大きさ には無関係であり，したがって $\beta_{i}$ の標準偏差 $\rho_{1}$ は前 述のように一定と推定される。

次に一定の $\sigma_{m}$ のもとで, くり返し載荷する偏差応力 の值を大きくすれば，砂はそれだけ高い弾性限界をもつ 弹性状態が得られる。弹性限界が高くなると, 粒子の接 触がより密になり, 粒子相互の固定度が増すので, 粒子 間力の伝達性が高まり， $\beta_{i}$ の分布も変化するようにも 思われる。しかし弾性状態にあるときは粒子が変形しな いかぎり粒子相互の配列関係が不変であるから $\beta_{i}$ の分 布幅すなわち標準偏差 $\rho_{1}$ は砂の弹性限界の值にはほと んど影響されずほぼ一定であると考えられる。すなわち 一定の材質・形状をもつ変形しにくい粒子の集合体にお いて，それを拘束する $\sigma_{m}$ が一定であり，かつその集合 体が同一偏差応力のくり返し載荷で作られた弾性状態に あるときは, $\beta_{i}, \theta_{i}$ の標準偏差 $\rho_{1}, \rho_{2}$ は弾性限界の值に 無関係にそれぞれ一定とみても差支えない。

またこのような粒子からなる砂の弾性状態が, 偏差応 力の多数の回数のくり返し載荷の結果得られるた場合に おいては， $\rho_{2}$ は $\rho_{1}$ に等しいと推定される。すなわち

$$
\left.\begin{array}{l}
\rho_{1}=\rho_{2} \\
\therefore \rho=\sqrt{\rho_{1}{ }^{2}+\rho_{2}{ }^{2}}=\sqrt{2} \cdot \rho_{2}
\end{array}\right\}
$$

ここの解析では, $\theta_{i}$ や $\beta_{i}$ の分布として両側無限の正 規確率分布を近似的に適用し, それらから導いた $N(m$, $\left.\rho^{2}\right)$ の確率積分によって滑動確率 $P$ を求めた。一般に正 規確率関数では平均值の両側に標準偏差の 3 倍の值の点 をとれば,この 2 点で定まる区間に確率変数の值が存在 する確率は周知のように $99.73 \%$ となり, 実際的見地か らみれば，平均值の両側にとったこれら 2 点（たとえば $3 \rho,-3 \rho)$ 注確率関数の有限の限界と考えても差支えな い。ここではこれら 2 点を $\pm 3 \rho$ 以上にとって $\pi \rho,-\pi \rho$ とすることにする。 $\theta_{i}$ の分布やその標準偏差 $\rho_{2}$ につい ても上記と同様である。すなわち $\theta_{i}$ (または $\theta_{i}+\delta$ ) は 一 $\pi \rho_{2}$ から $\pi \rho_{2}$ までの有限範囲に分布しているとみられ る。ゆえに

$$
\pi \rho_{2}=m_{2}-m_{-\infty}=m_{\infty}-m_{2}
$$

ここに $m_{-\infty}$ および $m_{\infty}$ は $m_{2}$ の座標原点からはかっ た $\left(\theta_{i}+\delta\right)$ の分布の下限 および上限を示す点の座標の 值である。

また一定の $\sigma_{m}$ のもとで, 一定の $\left(\sigma_{1}-\sigma_{3}\right)$ のくり返 乙載荷によって得られる弹性状態の砂の弾性限界は, 弹 性状態の生成される過程からも推論されるように，加え た $\left(\sigma_{1}-\sigma_{3}\right)$ の応力強度に等しい。たとえば図一1では点 Bがこの砂の弾性限界を示していることとなる。 


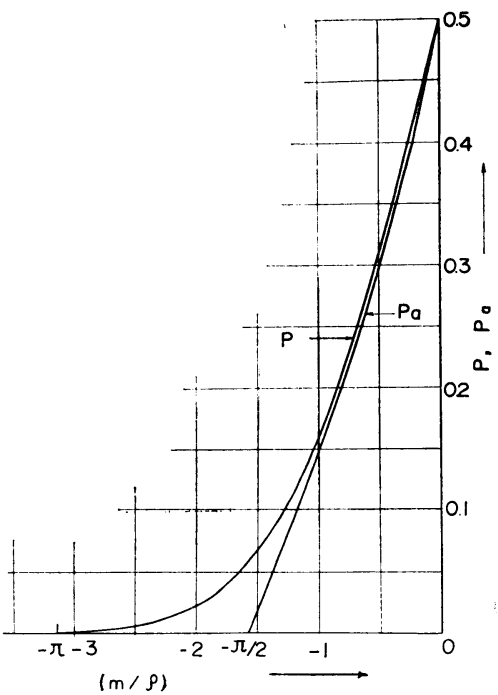

図-11

\section{8. 内部摩擦の最大稼働面上の応カ・ひずみ特性}

\section{(1) $(\tau / \sigma)_{\max }$-面上のせん断ひずみ $: \gamma_{\beta}$}

$m_{1}$ で示す偏差応力を $m_{2}$ で示す弾性状態の砂に加え たときの滑動確率 $P$ は式 (15) で示され, その值は数 表から求められるが，簡単に式示できない不便がある。 そのため演算の便宜上 $P$ を次式の正切関数 $P_{a}$ で近似 する。

$$
P_{a}=\frac{1}{2} \tan \left(\frac{\pi}{4}-\frac{m}{2 \rho}\right), \text { ここに } m=m_{2}-m_{1}
$$

$P, P_{\boldsymbol{a}}$ の様相は図一11 に示すように $m / \rho$ が大きい部 分では誤差が大きいが, $0<m / \rho<\pi / 3$ の範囲ではよく 一致し, その範囲では, 最大の誤差は $\pi / 3$ のところでも $10 \%$ である。等方圧下の砂の滑動確率 $P_{a 0}$ は，5．にの べたように $m_{1}=0$ を上式に代入して求められるから，等 方圧下の砂に $m_{1}$ で示す偏差応力を加えたときの滑動確 率の増加 $\left(P-P_{0}\right)$ は, 式 (31) を用いて次の $\left(P_{a}-P_{a 0}\right)$ で近似する。

$$
\begin{aligned}
P_{a}-P_{a 0}= & \frac{1}{2} \tan \left(\frac{\pi}{4}-\frac{m}{2 \rho}\right)-\frac{1}{2} \tan \left(\frac{\pi}{4}-\frac{\mathrm{m}_{2}}{2 \rho}\right) \\
= & \frac{1}{2}\left[\left\{1+\tan ^{2}\left(\frac{\pi}{4}-\frac{m_{2}}{2 \rho}\right)\right\} \tan \frac{m_{1}}{2 \rho}\right] / \\
& \cdot\left\{1-\tan \left(\frac{\pi}{4}-\frac{m_{2}}{2 \rho}\right) \cdot \tan \frac{m_{1}}{2 \rho}\right\}
\end{aligned}
$$

上式中 $(1 / 2) \cdot \tan \left\{(\pi / 4)-m_{2} /(2 \rho)\right\}$ 㩐方圧下の滑動 確率 $P_{a 0}$ の值であるから 1 に比べてかなり 小さい。ゆ えに $\tan \left\{(\pi / 4)-m_{2} /(2 \rho)\right\}$ の 2 乗の項およびこれと $\tan$ $\left(m_{1} / 2 \rho\right)$ との積の項を無視すると, 上式の $P_{a}-P_{a 0}$ は
近似的に

$$
P_{a}-P_{a 0} \doteqdot \frac{1}{2} \tan \frac{m_{1}}{2 \rho}
$$

上式右辺を $\tan m l_{1}$ の項で表わすため次のように変形す る。ここに $\alpha^{\prime}$ は両辺を等置するための補正項である。

$$
\tan \frac{m_{1}}{2 \rho}=\frac{1}{2 \rho} \tan m_{1}+\alpha^{\prime}
$$

$\alpha^{\prime}$ は $m_{1}=0$ では $\alpha^{\prime}=0$ となるが, $m_{1}$ が増すにつれ て増加し， $m_{1}$ が $m_{2}$ に達すると最大となる。この最大 の $\alpha^{\prime}$ を $\alpha_{0}^{\prime}$ とすると

$$
\alpha_{0}^{\prime}=\tan \left\{m_{2} /(2 \rho)\right\}-\tan m_{2} /(2 \rho)
$$

補正項は $\alpha^{\prime}$ は他の項に比べて比較的小さい值であるか ら, $\tan m_{1}$ が 0 から $\tan m_{2}$ に変わる間の $\alpha^{\prime}$ の変化 を近似的に直線变化と仮定すると

$$
\alpha^{\prime}=\alpha_{0}{ }^{\prime} \cdot \tan m_{1} / \tan m_{2}
$$

これらの関倸を前式に入れて $\tan \left\{m_{1} /(2 \rho)\right\}$ を示すと

$$
\tan \frac{m_{1}}{2 \rho}=\left\{\frac{1}{2} \tan \frac{m_{2}}{2 \rho} / \tan m_{2}\right\} \cdot \tan m_{1}
$$

上式を前記の $P-P_{0}$ の近似式 $P_{a}-P_{a 0}$ に入れると

$$
\left.\begin{array}{l}
P-P_{0} \doteqdot P_{a}-P_{a 0}=W_{e} \cdot \tan m_{1} \\
W_{e}=(1 / 2) \cdot \tan \left\{m_{2} /(2 \rho)\right\} /\left(\tan m_{2}\right)
\end{array}\right\}
$$

前節で式 (18) を求めるときのべたように， $\lambda_{s}$ はあ る載荷応力のもとで粒子が隣接斜面上を滑動し始めてか らその斜面の potential 障壁に当って滑動を停止するま での移動距離の $(\tau / \sigma)_{\max }$-面への投影長さである。ゆえ に $\lambda_{s}$ は粒子の形状, 寸法や配列が同一であっても, 滑 動粒子群が滑動する斜面の $(\tau / \sigma)_{\mathrm{max}}$-面からの平均傾斜 角 $\theta_{s}$ や粒子間摩擦角 $\delta$ によって变化する。一方弾性状 態にある砂の粒子構造は外力によって変わらないから， 粒子の滑動可能な距離の平均值は，その砂の粒子性状や 粒子配列によってのみ定まり，外力の大きさや $\theta_{s}, \delta$ に 無関係な固有な值が存在するものと推定される。この滑 動可能な一定の距離を $\Lambda$ とする。冬 から $\theta_{s}$ と $\delta$ の影響 を除くため，滑動粒子が実際に滑動する平均傾斜角 $\theta_{s}$ の斜面の代わりに $\left(\theta_{s}+\delta\right)$ の傾斜角の斜面を仮想し, 摩 擦のない粒子がこの仮想斜面を滑動するとする。仮想斜 面に対する力のつり合い条件は実際斜面のそれと変わら ないから， $\lambda_{s}$ に含まれている $\theta_{s}$ と $\delta$ の影響を除いた 関係としては， $\lambda_{s}$ は仮想斜面にそう $\Lambda$ の $(\tau / \sigma)_{\max }$-面 への投影長さに等しいという関係が用いられる。滑動粒 子は仮想斜面上では粒子間力とつり合うので仮想斜面の $(\tau / \sigma)_{\max }$-面からの傾斜角はその粒子に作用する粒子間 力の方向角に等しく，またこの粒子間力の方向角の滑動 粒子に対する平均值は $\beta$ にほぼ等しい。ゅえに $\lambda_{s}$ と $\Lambda$ の関係は近似的に

$$
\lambda_{s}=\Lambda \cdot \cos \left(\theta_{s}+\delta\right) \div \Lambda \cdot \cos \beta
$$

なお上式の $\cos \beta$ は式 (1)，(5) より 


$$
\cos \beta=\cos \phi=1 / \sqrt{1+z^{2}}
$$

上の 2 式と式 (32) を式 (19) に代入すると

$$
\begin{aligned}
& \gamma_{\beta}\left(=A \cdot P_{e} / \sqrt{1+z^{2}}\right)=A \cdot W_{e} \cdot z / \sqrt{1+z^{2}} \\
& P_{e}\left(=P-P_{0}\right)=W_{e} \cdot z \\
& A=c \cdot A \cdot N / d, \\
& W_{e}=(1 / 2) \tan \left\{\tan ^{-1} s_{e l} /(2 \rho)\right\} / s_{e l} \\
& z=\tan m_{1}(=\tan \beta=\tau / \sigma), s_{e l}=\tan m_{2}
\end{aligned}
$$

上式は弹性状態にある砂が, 有効主応力 $\sigma_{1}, \sigma_{2}, \sigma_{3}\left(\sigma_{1}\right.$ $\left.>\sigma_{2}=\sigma_{3}\right)$ をうけたとき, $\sigma_{1}$ と $\sigma_{2}$ または $\sigma_{1}$ と $\sigma_{3}$ の 2 主応力によって生成される内部摩擦の最大稼働面上の せん断ひずみ $\gamma_{\beta}$ とその面上の応力比 $\tau / \sigma$ との関係を示 寸式である。ここにAは弾性状態にある粒子の変位に関 する係数で, 変位係数 (displacement factor) と名付け, その砂に固有な定数, $W_{e}$ (添字 $e$ は弾性状態の意) は 粒子の配列に支配されるから弾性状態における構造係数 (structural factor) と称することとする。 $W_{\boldsymbol{e}}$ は弾性限 界 $s_{e l}$ と $\rho$ の関数であるが, $\rho$ は前述のように一定の 砂ではほぼ一定とみられるから, $W_{e}$ は $s_{e l}$ によって変 化する。通常 $\rho$ は $2 \rho(\mathrm{rad})<1$ と推定されるので, $s_{e l}$ が増大すると $W_{e}$ はいくらか減少するが, $s_{e l}$ の変 動範囲は通常あまり大きくないから，We $W_{e}$ はその砂に固 有なほぼ一定の定数とみなすことができる。 $z$ は内部摩 擦の最大稼働面 $\left((\tau / \sigma)_{\max }\right.$-面）上の垂直応力とせん断 応力の比である。

\section{（2） $(\tau / \sigma)_{\max }$-面上の体積ひずみ： $\varepsilon_{n}$}

砂の弾性状態が一定荷重の繰り返し載荷によって得ら れた場合を想定して，式（29）を式（28）に代入すると

$$
\lambda\left(-\frac{d \varepsilon_{n}}{d r_{\beta}}\right)+\tan \delta=\tan \left(\frac{m_{1}+m_{2}}{2}\right)
$$

上式右辺を $m_{1}, m_{2}$ それぞれの正切で示すため次のよう におく。ここにはは補正のための項である。

$$
\tan \frac{m_{1}+m_{2}}{2}=\frac{1}{2}\left(\tan m_{1}+\tan m_{2}-\alpha\right)
$$

$\alpha$ は $m_{1}=m_{2}$ では $\alpha=0$ となるが, $m_{1}$ が $m_{2}$ より 減少するにつれて増加し， $m_{1}=0$ では $\alpha=\alpha_{0}$ となる。 $\alpha$ は小さいから $0 \sim m_{2}$ の範囲では近似的に 直線変化を するとみなすと，

$$
\begin{aligned}
& \alpha=\frac{\tan m_{2}-\tan m_{1}}{\tan m_{2}} \alpha_{0} \\
& \alpha_{0}=\tan m_{2}-2 \tan \left(m_{2} / 2\right)
\end{aligned}
$$

式 (33) のように $\tan m_{1}$ を $z$ で, $\tan m_{2}$ を $s_{e l}$ で示 すと,

$$
\begin{aligned}
\tan \frac{m_{1}+m_{2}}{2} & =\frac{s_{e l}+z}{2}-\frac{s_{e l}-z}{2} \cdot \frac{\alpha_{0}}{s_{e l}} \\
& =\frac{s_{e l}-\alpha_{0}}{2}+\left(\frac{s_{e l}+\alpha_{0}}{2 s_{e l}}\right) z
\end{aligned}
$$

この関倸を本項はじめの式に代入すると，

$$
\lambda\left(-\frac{d \varepsilon_{n}}{d r_{\beta}}\right)+\tan \delta=\frac{s_{e l}-\alpha_{0}}{2}+\frac{s_{e l}+\alpha_{0}}{2 s_{e l}} z
$$

式（33）を $z$ で微分した結果は

$$
d \gamma_{\beta} / d z=A \cdot W_{e} / \sqrt{\left(1+z^{2}\right)^{3}}
$$

上式を式 (34) に代入して, $z=0$ と $\varepsilon_{n}=0$ を積分下限 として積分し，さらにそれに式 (33) を代入すると

$$
\begin{aligned}
-\varepsilon_{n}= & \frac{A \cdot W_{e} \cdot z}{\lambda \sqrt{1+z^{2}}}\left\{\frac{s_{e l}-\alpha_{0}}{2}-\tan \delta+\frac{s_{e l}+\alpha_{0}}{2 s_{e l}}\right. \\
& \left.\cdot \frac{\sqrt{1+z^{2}}-1}{z}\right\}=\frac{\gamma_{\beta}}{\lambda}\left\{\frac{s_{e l}-\alpha_{0}}{2}-\tan \delta\right. \\
& \left.+\frac{s_{e l}+\alpha_{0}}{2 s_{e l}} \cdot \frac{\sqrt{1+z^{2}}-1}{z}\right\}
\end{aligned}
$$

$z$ が 1 に比べて小さいときは上式右辺第 2 項の $\sqrt{1+z^{2}}$ は $\sqrt{1+z^{2}} \doteqdot 1+z^{2} / 2$ と近似できるから, 上式は

$$
\lambda\left(-\frac{\varepsilon_{n}}{r_{\beta}}\right)+\tan \delta=\frac{s_{e l}-\alpha_{0}}{2}+\frac{s_{e l}+\alpha_{0}}{4 s_{e l}} z
$$

砂の弾性状態が応力比 $z$ のくり返しで作られた場合の $d \varepsilon_{n} / d r_{\beta}, \varepsilon_{n} / r_{\beta}$ と $z$ との関倸はそれぞれ式 (34)，(35)

で示され, 前者を横軸, 後者を縦軸として図示すればい ずれも直線となる。両直線は $z$ の項の係数以外の係数お よび定数項が同一であるから，両直線は横軸上の同一点 において交わる。また式 (34)，(35）の示す直線の横軸 となす傾斜角は $1: 2$ となる。式 (34) の直線が縦軸を 切る点の縦距を $z_{0}$ とすれば, $z_{0}$ は

$$
z_{0}=2 s_{e l}\left\{\tan \delta-\left(s_{e l}-\alpha_{0}\right) / 2\right\} /\left(s_{e l}+\alpha_{0}\right)
$$

$\alpha_{0}$ の值は, $s_{e l}=0.47 \sim 1.00\left(m_{2}=25^{\circ} \sim 45^{\circ}\right)$ に対して $\alpha_{0}=0.023 \sim 0.172$ と小さいから, 上式の $\alpha_{0}$ を無視す ると

$$
z_{0}+s_{e l} \doteqdot 2 \tan \delta
$$

すなわち縦軸上に $s_{e l}, \tan \delta$ をとれば, $\tan \delta$ の綐距は $z_{0}$ と $s_{e l}$ の縦距のほぼ中点となることが知られる。

また弾性状態における砂の $\varepsilon_{n}$ の変化は式 (35) が示 すように， $z$ の 2 次曲線で近似することができる。

\section{9. 弾性状態にある砂の構成式}

構成式のあらわし方には種々の形式があるが，ここで は主応力・主ひずみ関係で示す。構成式は平均有効主応 力と偏差応力に対するひずみ特性が含まれるのが一般で あるが， $\sigma_{m}$ の影響は別の機会にのべるので，ここでは $\sigma_{m}$ が一定の場合の偏差応力に 対する特性だけに限定す る。したがってここにのべる構成関係は， $\sigma_{m}$ を一定に保 てるような載荷形式でなければならないから, 三軸圧縮 と三軸伸長の 2 状態を対象とした。前項 8.では， $\sigma_{m}$ 定のもとで $\left(\sigma_{1}-\sigma_{3}\right)$ を載荷したときの $(\tau / \sigma)_{\max }$-面上 
の $\varepsilon_{n}$ と $r_{\beta}$ を求めたので，それらを主応力・主ひずみ 関倸に変換すればよいこととなる。

まず 3 主応力のうち $\sigma_{1}$ と $\sigma_{3}$ が作用する主応力面 1 一III 面内の関係をみる。

有効主応力 $\sigma_{1}, \sigma_{3}$ や $(\tau / \sigma)_{\mathrm{max}}$-面上の $\sigma, \tau$ などの応 力関係は図一3の Mohr の応力円で示した。砂が均質・ 等方であれば, 主ひずみの方向と主応力の方向は一致す るから, 図一3 の応力円に対応する Mohr のひずみ円 を想定すると主ひずみ $\varepsilon_{1}, \varepsilon_{3}$ と $(\tau / \sigma)_{\max }$-面上の $\varepsilon_{n}, \gamma_{\beta}$ の関係は周知の次の関係で示さ礼る。な掞各応力, 各ひ ずみとも圧縮の場合を正としている。

$$
\left.\begin{array}{l}
\varepsilon_{n}=\frac{\varepsilon_{1}+\varepsilon_{3}}{2}-\frac{\varepsilon_{1}-\varepsilon_{3}}{2} \sin \phi \\
r_{\beta}=\left(\varepsilon_{1}-\varepsilon_{3}\right) \cdot \cos \phi
\end{array}\right\}
$$

式 (37) より $\varepsilon_{1}, \varepsilon_{3}, r$ (最大せん断ひずみ) は次のよう になる。

$$
\begin{aligned}
& \varepsilon_{1}=\varepsilon_{n}+\gamma_{\beta}(1+\sin \phi) /(2 \cos \phi) \\
& \varepsilon_{\beta}=\varepsilon_{n}-\gamma_{\beta}(1-\sin \phi) /(2 \cos \phi) \\
& r=\varepsilon_{1}-\varepsilon_{3}=\gamma_{\beta} / \cos \phi,
\end{aligned}
$$

一方, 式 (33) にならって $(\tau / \sigma)_{\max }=z$ とおき, $\phi$ の 正弦, 余弦, 正切と $\sigma_{1}, \sigma_{3}$ または $z$ との関倸を式 (1) を用いて計算すると，

$$
\begin{aligned}
\tan \phi & =\frac{\sigma_{1}-\sigma_{3}}{2 \sqrt{\sigma_{1} \cdot \sigma_{3}}}=\frac{1}{2}\left(\sqrt{\frac{\sigma_{1}}{\sigma_{3}}}-\sqrt{\frac{\sigma_{3}}{\sigma_{1}}}\right) \\
& =\left(\frac{\tau}{\sigma}\right)_{\max }=z \\
\sin \phi & =\frac{\sigma_{1}-\sigma_{3}}{\sigma_{1}+\sigma_{3}}=\frac{z}{\sqrt{z^{2}+1}} \\
\cos \phi & =\frac{2 \sqrt{\sigma_{1} \cdot \sigma_{3}}}{\sigma_{1}+\sigma_{3}}=\frac{1}{\sqrt{z^{2}+1}}
\end{aligned}
$$

上式中の $z$ は， $\sigma_{1}, \sigma_{3}\left(\sigma_{1}>\sigma_{3}\right)$ から遒かれたものであ るから, この $z$ には $z_{1 \cdot 3}$ のように応力の大きさの順に, 1,3 の添字をつけたうえ, 上記の関係を前式に代入して $\varepsilon_{1}, \varepsilon_{3}, r$ を求める。

$$
\begin{aligned}
& \varepsilon_{1}=\varepsilon_{n}+\left(\gamma_{\beta} / 2\right)\left\{\sqrt{z_{1 \cdot 3}{ }^{2}+1}+z_{1 \cdot 3}\right\} \equiv G\left(\sigma_{1} / \sigma_{3}\right) \\
& \varepsilon_{3}=\varepsilon_{n}-\left(\gamma_{\beta} / 2\right)\left\{\sqrt{z_{1 \cdot 3}{ }^{2}+1}-z_{1 \cdot 3}\right\} \equiv H\left(\sigma_{1} / \sigma_{3}\right) \\
& \gamma=\gamma_{\beta} \cdot \sqrt{z_{1 \cdot 3}{ }^{2}+1} \\
& \text { ここに } z_{1 \cdot 3}=\frac{1}{2}\left(\sqrt{\frac{\sigma_{1}}{\sigma_{3}}}-\sqrt{\frac{\sigma_{3}}{\sigma_{1}}}\right)
\end{aligned}
$$

\begin{tabular}{|c|c|c|c|c|}
\hline $\begin{array}{l}\text { Principal } \\
\text { planes }\end{array}$ & $\begin{array}{l}\text { Comparison } \\
\text { between } 2 \\
\text { principal } \\
\text { stresses }\end{array}$ & $\varepsilon_{1}$ & $\varepsilon_{2}$ & $\varepsilon_{3}$ \\
\hline I-II & $\sigma_{1}>\sigma_{2}$ & $G\left(\sigma_{1} / \sigma_{2}\right)$ & $H\left(\sigma_{1} / \sigma_{2}\right)$ & \\
\hline I-III & $\sigma_{1}>\sigma_{3}$ & $G\left(\sigma_{1} / \sigma_{3}\right)$ & & $H\left(\sigma_{1} / \sigma_{3}\right)$ \\
\hline III-III & $\sigma_{2}=\sigma_{3}$ & & 0 & 0 \\
\hline $\begin{array}{l}\text { Total } \\
\text { strain }\end{array}$ & & $G\left(\frac{\sigma_{1}}{\sigma_{3}}\right)+G\left(\frac{\sigma_{1}}{\sigma_{2}}\right)$ & $H\left(\frac{\sigma_{1}}{\sigma_{2}}\right)$ & $H\left(\frac{\sigma_{1}}{\sigma_{8}}\right)$ \\
\hline
\end{tabular}

上式は， $\sigma_{1}, \sigma_{3}$ の 2 主応力の作用する場においては,

\begin{tabular}{|c|c|c|c|c|}
\hline $\begin{array}{l}\text { Principal } \\
\text { planes }\end{array}$ & $\begin{array}{l}\text { Comparison } \\
\text { between } 2 \\
\text { principal } \\
\text { stresses }\end{array}$ & $\varepsilon_{1}$ & $\varepsilon_{2}$ & $\varepsilon_{3}$ \\
\hline$I-I I$ & $\sigma_{1}<\sigma_{2}$ & $H\left(\sigma_{2} / \sigma_{1}\right)$ & $\boldsymbol{G}\left(\sigma_{2} / \sigma_{1}\right)$ & \\
\hline I-III & $\sigma_{1}<\sigma_{8}$ & $H\left(\sigma_{3} / \sigma_{1}\right)$ & & $G\left(\sigma_{3} / \sigma_{1}\right)$ \\
\hline II $-\mathrm{II}$ & $\sigma_{2}=\sigma_{3}$ & & 0 & 0 \\
\hline $\begin{array}{l}\text { Total } \\
\text { strain }\end{array}$ & & $H\left(\frac{\sigma_{2}}{\sigma_{1}}\right)+H\left(\frac{\sigma_{8}}{\sigma_{1}}\right)$ & $G\left(\frac{\sigma_{2}}{\sigma_{1}}\right)$ & $G\left(\frac{\sigma_{8}}{\sigma_{1}}\right)$ \\
\hline
\end{tabular}
大きい方の主応力 $\sigma_{1}$ 方向に生ずるひずみ $\varepsilon_{1}$ は上式の $G\left(\sigma_{1} / \sigma_{3}\right)$ の関数を用いることによって, 小さい主応力 $\sigma_{3}$ 方向のびずみ $\varepsilon_{3}$ は $H\left(\sigma_{1} / \sigma_{3}\right)$ の関数を用いて求めら れることを示している。なお関数中の $r_{\beta}, \varepsilon_{n}$ はそれぞ れ式 (33)，(35) によって求めたものを代入する。

このような関係は, 主応力・主ひずみ関係が各主応力 間で独立であるとすると $\sigma_{1}, \sigma_{2}$ に対するI－II 面につい
表-1 In Case of Triaxial Compression : $\left(\sigma_{1}>\sigma_{2}=\sigma_{3}\right)$

$\varepsilon_{1}: G\left(\frac{\sigma_{1}}{\sigma_{3}}\right)+G\left(\frac{\sigma_{1}}{\sigma_{2}}\right)=2 G\left(\frac{\sigma_{1}}{\sigma_{3}}\right)$

表-2 In Case of Triaxial Extension: $\left(\sigma_{1}<\sigma_{2}=\sigma_{3}\right)$

ても同様に成立する。亲に $\sigma_{1}$ 方向の主ひずみは I-III 面とI－II面の両方から発生することになるから，実際 の $\sigma_{1}$ 方向のひずみはこれら両者の和となる。な顺一正 面については， $\sigma_{2}=\sigma_{3}$ であるから $z_{2 \cdot 3}=0$ となって， $z_{2 \cdot 3}$ からの主ひずみは発生しない。上述の招いを， $\sigma_{m}$ が一 定の三軸圧縮, 三軸伸長について表によって示すとそれ ぞれ表一1,2 となる。すなわち主ひずみおよび体積ひず み $\Delta V / V$ (圧縮を正) は次のようになる。

3 軸圧縮 $\left(\sigma_{1}>\sigma_{2}=\sigma_{3}\right)$ に対しては,

$$
\begin{aligned}
& \varepsilon_{1}=2 G\left(\frac{\sigma_{1}}{\sigma_{3}}\right), \quad \varepsilon_{2}=\varepsilon_{3}=H\left(\frac{\sigma_{1}}{\sigma_{3}}\right) \\
& \left(\frac{\Delta V}{V}\right)_{c}=\varepsilon_{1}+\varepsilon_{2}+\varepsilon_{3}=2\left\{G\left(\frac{\sigma_{1}}{\sigma_{3}}\right)+H\left(\frac{\sigma_{1}}{\sigma_{3}}\right)\right\}
\end{aligned}
$$

3 軸伸長 $\left(\sigma_{1}<\sigma_{2}=\sigma_{3}\right)$ に対しては

$$
\begin{aligned}
& \varepsilon_{1}=2 H\left(\frac{\sigma_{3}}{\sigma_{1}}\right), \quad \varepsilon_{2}=\varepsilon_{3}=G\left(\frac{\sigma_{3}}{\sigma_{1}}\right) \\
& \left(\frac{\Delta V}{V}\right)_{e}=2\left\{G\left(\frac{\sigma_{3}}{\sigma_{1}}\right)+H\left(\frac{\sigma_{3}}{\sigma_{1}}\right)\right\}
\end{aligned}
$$

これらの結果を種々の場合に適用して実際の砂の特性 と比較することは興味あることである。一例として一定 の $\sigma_{m}$ のもとで偏差応力をくり返し載荷して作った弹性 状態の砂を $\sigma_{m}$ 一定の条件で三軸圧縮する場合のダイラ タンシーをみると, 砂が弾性限界において原体積より膨 張するためには， $z=s_{e l}$ において $(\Delta V / V)_{c}<0$ が成立 せねばならない。 $(\Delta V / V)_{c}$ に式 (33), (35), (38)を 代入し， $z=s_{e l}$ とおくと， $(\Delta V / V)_{c} \leq 0$ になるための $s_{e l}$ の条件は,

$$
s_{e l} \geq\left(2 \tan \delta+0.5 \alpha_{0}\right) /(1.5-\lambda)
$$

となる。入は 1 に近い係数であり， $\alpha_{0}$ の数值も 1 より小 
さいからこのような $s_{e l}$ は実際の砂で作ることは無理 である。ゅえに弾性状態では砂のダイラタンシーによる 体積変化は，量の多少は別として，ほとんどすべて圧縮 側にあることが知られる。

\section{0. 結带}

本文は，一定の平均有効主応力のもとにおかれた弾性 状態にある砂の偏差応力に対する構成式を求めるためあ らたな手法の開発を試みたものである。

ここで定義した砂の弾性状態といら言葉は, いままで 明確に意識されていなかった砂の一状態に対する新しい 言葉であると思う。このような概念を設けなりればなら なかった理由は, 弾性状態は砂の構成式を決定する場合 にその原点の部分を形成する非常に重要な状態であるか らである。ゅえにもし弾性状態につづいて発生する塑性 状態や破壞状態を, 弾性状態からの位置ゔけなしに求め ようとすれば，それらの後続状態がおかれる座標を合理 的に決めにくくなることになろう。

本文では, 砂を摩擦性粒子の random assembly とす る前提のもとに, 統計力学的考察によって弾性状態にあ る砂の構成式を理論的に誘導した。これによって, 砂の 弾性状態污打る偏差応力とひずみの関係が式示できる とともに, 解析の誘導過程に引用した諸因子に対する物 性論的意義を明らかにすることができた。

なお本研究において, 確率論に関しては角屋睦教授か ら有益な助言をいただき,また砂の弾性状態の実験例に ついては岩井国臣氏（昭 37 修士，現建設省勤務）の修 士論文の一部を用いたことをのべ，ここに両氏に深く謝 意を表する次第である。

\section{引用 文 献}

1) Murayama, S. : A Theoretical Consideration on a Behavior of Sand, Proc. IUTAM Symposium on Rheology and Soil Mech., Grenoble, 1964, pp. 146157, Springer-Verlag, 1966.

Murayama, S. : Stress-Strain-Time Behavior of Soils Subjected to Deviatoric Stress, Proc. 7th Int. Conf. Soil Mech. and Foundation Eng., Vol. I, 1969, pp. 297-305.

2) Newland, P.L. and B.H. Allely : Volume Change in Drained Triaxial Tests on Granular Materials, Geotechnique, Vol. 7, No. 17, 1957, pp. 17-34.

3) Rowe, P.W.: The Stress-dilatancy Relation for Static Equilibrium of an Assembly of Particles in Contact, Proc. Royal Society, London, Series A, Vol. 269, 1962, pp. 500-527.

4) Mogami, T. : A Statistical Approach to the Mechanics of Granular Materials, Soils and Foundations, Vol. V, No. 2, 1965, pp. 26-36.

Mogami, T.: Mechanics of Granular Material as a Particulated Mass, Proc. 7th Int. Conf. Soil Mech. and Foundation Eng., Vol. I, 1969, pp. 281-285.

5）村山朔郎・松岡 元：2 次元モデルによる粒状体のせえ 断現象の微視的考察, 京大防災研究所年報 13 号-B, 1970, pp. $505-523$.

村山朔郎・松岡 元: 砂々粘土のせえ断特性の類似性と そのメカニズムについて, 京大防災研究所年報 14 号-B， 1971, pp. 551-563.

Murayama, S. and H. Matsuoka : A Microscopic Study on Shearing Mechanism of Soils, Proc. 8 th Int. Conf. Soil Mech. and Foundation Eng., Vol. 1, Part 2, 1973, pp. 293-298.

6) Reiner, M. : Building Materials, North-Holland Publishing Co., 1954, p. 428.

7) Ditto 6), p. 427.

8) Bishop, A.W. and G. Eldin : Undrained Triaxial Tests on Saturated Sands and Their Significance in the Granular Theory of Shear Strength, Geotechnique, Vol. 2, No. 1, 1950, pp. 13-32.

(1974.10.22 - 受付) 